\title{
Noninvasive Ventilatory Support: The Detail Lies in the Interface
}

Over the last decade, the use of noninvasive ventilatory support has expanded considerably ${ }^{1}$ for both children ${ }^{2}$ and adults. ${ }^{3}$ The options are extensive, ranging from high-flow humidified nasal oxygen ${ }^{4}$ to noninvasive ventilation (NIV) using techniques such as negative-pressure ventilation, ${ }^{5}$ neurally adjusted ventilatory assist, ${ }^{6}$ and multiple modes of ventilation. ${ }^{7}$ The indications are ever expanding and now include patients with terminal disease, ${ }^{8-10}$ chronic and acute respiratory disease ${ }^{11}$ (or both), following cardiac surgery, ${ }^{12}$ hemodynamic instability, muscular weakness, and central hypoventilation. The settings of use have expanded from ICUs to include emergency care, ${ }^{4,13}$ transport systems, ${ }^{14}$ ward care, home care, and many variations of care delivery, the one consistent theme being that patients should be able to protect their airways from aspiration or obstruction.

The benefits derived from NIV appear to be substantial over a range of age groups and multiple patient groups in many diverse settings. The benefits have included improved survival, ${ }^{15}$ a reduction in the adverse events related to endotracheal intubation, reductions in ICU and hospital stay, and significantly reduced costs to health-care systems and to patients, ${ }^{16}$ and in some parts of the world, this technology has provided access to ventilatory support that was simply not available before. ${ }^{17}$ In settings such as status asthmaticus, there is a suggestion that some modes of NIV relieve symptoms but may also reduce airway reactivity. ${ }^{18}$ However, there remains a paucity of randomized, controlled studies to fully evaluate the impact of NIV, particularly in children. ${ }^{19}$

Throughout this expansion, one of the most challenging aspects of practical care has been the interface between the patient and the ventilator, between the ventilator circuit and the patient's airway, and between the patient's respiratory efforts and the ventilator. In many settings, one of the strongest motivations for use of noninvasive ventilatory support is limitation of adverse events associated with

\footnotetext{
Dr Argent has disclosed no conflicts of interest.

Correspondence: Andrew C Argent MB BCh MMed(Paeds) MD (Paeds) DCH(SA) FCPaeds(SA) FRCPCH(UK), Red Cross War Memorial Children's Hospital, Rondebosch, Cape Town 7700, South Africa. E-mail: andrew.argent@uct.ac.za.
}

DOI: $10.4187 /$ respcare.04492 invasive ventilation (with endotracheal and/or tracheostomy tubes), yet adverse events are common for patients receiving NIV, with damage to skin and facial structures being particularly frequent events, ${ }^{20}$ whereas many other patients suffer discomfort related to the mask/interface.

See the Original Study on Page 1536

A wide range of interfaces (full face mask, oronasal mask, nasal mask) have been introduced to adapt to a variety of situations. More recently, nasal cannulae and helmets $^{21,22}$ have been added to the armamentarium. In some children, use of a nasopharyngeal tube has been an effective route of NIV. ${ }^{23}$ Some of the challenges related to interfaces include: discomfort (particularly in patients who are struggling to breathe); development of pressure damage to the skin and underlying structures; inappropriate humidification; ventilatory dead space; and problems with the triggering and pressure delivery from the ventilator system, particularly when leaks are present (which may be exacerbated by the presence of nasogastric tubes). The selection of the particular interface may be further complicated by the attached ventilator tubing systems, since the drag and weight of the system may exert significant pressure on areas of the face.

These challenges are exacerbated by the fact that many of the patients who require noninvasive ventilatory support may have facial structures that differ from the norm, ${ }^{24}$ creating challenges for the selection of the optimal interface. In a pediatric population, the challenges may be even more striking because children come in a wide range of sizes and facial shapes and have skin that (particularly in neonates and preterm infants) may be exceptionally fragile and liable to injury; also, children may find it difficult to tolerate sensations that adult patients may find acceptable. Some clinicians have used the helmet approach, where there is actually no contact of the interface with the face, and there is a significant body of evidence suggesting that many children find the helmet acceptable. ${ }^{21,22,25,26}$ However, this interface is not available in the United States.

In this issue of the Journal, Visscher et $\mathrm{al}^{27}$ have started to address many aspects of this interface using innovative technologies on a relatively large group of subjects (most pediatric and with a high proportion of craniofacial abnormalities). They used high definition color photography 
(with selection of red pixels) to identify early pressure damage to the skin. Only $28 \%$ of subjects had no visible skin compromise. In this process, they have highlighted the availability of techniques that can be used to identify early skin damage, ${ }^{28}$ regardless of skin pigmentation. They also measured skin hydration in relation to the NIV interface, of particular interest because the surfaces of NIV masks are often occlusive in nature, resulting in increased skin moisture with possible changes in susceptibility to injury from pressure or friction. ${ }^{29}$ They were able to examine some of the effects of different materials between the face and the mask, showing that cloth materials were associated with less skin hydration and erythema.

In addition, Visscher et al $^{27}$ used an innovative 3-dimensional imaging process to evaluate the fit between the face and the mask. This particular technique was challenging and in some ways produced an artificial situation because it was not possible to consider how the face and the mask might mold together, and it assumed that pressure or indentation had the same effects throughout the face. It is likely that the pressure effects will most affect skin and subcutaneous tissue that is caught between the mask and underlying bone. The particular damage that results will probably depend on the qualities of the skin, the patient's hemodynamic status, and the actual pressures produced. However, Visscher et $\mathrm{al}^{27}$ have highlighted the need for masks that fit the individual patient appropriately. This echoes the call from other authors ${ }^{23,24,30-32}$ for the utilization of interfaces that are fitted to individual patients. However, this intervention depends heavily on the experience and expertise of the therapists involved. That becomes challenging as NIV moves from highly specialized pediatric ICUs to less well-equipped areas.

There is clearly a need for intensive research focused on the ideal interface: how to provide a mass-produced commercially available interface that is comfortable; adaptable to a wide range of facial shapes and structures; lined with material that prevents overhydration of the skin; and can be fitted (together with the ventilator circuit) in such a way that it does not leak, increase dead space, or compromise patient-ventilator synchrony. The techniques that the authors have introduced may well open doors to new developments.

\section{Andrew C Argent MB BCh MMed(Paeds) MD (Paeds) DCH(SA) FCPaeds(SA) FRCPCH(UK)}

School of Child and Adolescent Health University of Cape Town

Paediatric Intensive Care

Red Cross War Memorial Children's Hospital Cape Town, South Africa

\section{REFERENCES}

1. Cabrini L, Esquinas A, Pasin L, Nardelli P, Frati E, Pintaudi M, et al. An international survey on noninvasive ventilation use for acute respiratory failure in general non-monitored wards. Respir Care 2015; 60(4):586-592.

2. Pavone M, Verrillo E, Caldarelli V, Ullmann N, Cutrera R. Noninvasive positive pressure ventilation in children. Early Hum Dev 2013;89(Suppl 3):S25-S31.

3. Walkey AJ, Wiener RS. Use of noninvasive ventilation in patients with acute respiratory failure, 2000-2009: a population-based study. Ann Am Thorac Soc 2013;10(1):10-17.

4. Kelly GS, Simon HK, Sturm JJ. High-flow nasal cannula use in children with respiratory distress in the emergency department: predicting the need for subsequent intubation. Pediatr Emerg Care 2013; 29(8):888-892.

5. Shah PS, Ohlsson A, Shah JP. Continuous negative extrathoracic pressure or continuous positive airway pressure compared to conventional ventilation for acute hypoxaemic respiratory failure in children. Cochrane Database Syst Rev 2013;(11):CD003699.

6. Clement KC, Thurman TL, Holt SJ, Heulitt MJ. Neurally triggered breaths reduce trigger delay and improve ventilator response times in ventilated infants with bronchiolitis. Intensive Care Med 2011;37(11); 1826-1832.

7. DiBlasi RM. Neonatal noninvasive ventilation techniques: do we really need to intubate? Respir Care 56(9):1273-1294, 2011; discussion 1295-1277.

8. Azoulay E, Demoule A, Jaber S, Kouatchet A, Meert AP, Papazian L, Brochard L. Palliative noninvasive ventilation in patients with acute respiratory failure. Intensive Care Med 2011;37(8):1250-1257.

9. Azoulay E, Kouatchet A, Jaber S, Lambert J, Meziani F, Schmidt M, et al. Noninvasive mechanical ventilation in patients having declined tracheal intubation. Intensive Care Med 2013;39(2):292-301.

10. Azoulay E, Kouatchet A, Jaber S, Meziani F, Papazian L, Brochard L, Demoule A. Non-invasive ventilation for end-of-life oncology patients. Lancet Oncol 2013;14(6):e200-e201.

11. Calderini E, Chidini G, Pelosi P. What are the current indications for noninvasive ventilation in children? Curr Opin Anaesthesiol 2010; 23(3):368-374.

12. Pons Odena M, Piqueras Marimbaldo I, Segura Matute S, Balaguer Argallo M, Palomeque Rico A. [Non-invasive ventilation after cardiac surgery: a prospective study] An Pediatr (Barc) 71(1):13-19, 2009. Article in Spanish.

13. Vitaliti G, Wenzel A, Bellia F, Pavone P, Falsaperla R. Noninvasive ventilation in pediatric emergency care: a literature review and description of our experience. Expert Rev Respir Med 2013;7(5):545552.

14. Fleming PF, Richards S, Waterman K, Davis PG, Kamlin CO, Sokol J, Stewart M. Use of continuous positive airway pressure during stabilisation and retrieval of infants with suspected bronchiolitis. J Paediatr Child Health 2012;48(12):1071-1075.

15. Cabrini L, Landoni G, Oriani A, Plumari VP, Nobile L, Greco M, et al. Noninvasive ventilation and survival in acute care settings: a comprehensive systematic review and metaanalysis of randomized controlled trials. Crit Care Med 2015;43(4):880-888.

16. Essouri S, Laurent M, Chevret L, Durand P, Ecochard E, Gajdos V, et al. Improved clinical and economic outcomes in severe bronchiolitis with pre-emptive nCPAP ventilatory strategy. Intensive Care Med 2014;40(1):84-91.

17. Kawaza K, Machen HE, Brown J, Mwanza Z, Iniguez S, Gest A, et al. Efficacy of a low-cost bubble CPAP system in treatment of respiratory distress in a neonatal ward in Malawi. PLoS One 2014; 9(1):e86327.

18. Pellegrino R, Pellegrino GM, Brusasco V. CPAP as a novel treatment for bronchial asthma? J Appl Physiol 2011;111(2):343-344. 


\section{Noninvasive Ventilatory Support: The Detail Lies in the Interface}

19. Marohn K, Panisello JM. Noninvasive ventilation in pediatric intensive care. Curr Opin Pediatr 2013;25(3):290-296.

20. Fauroux B, Lavis JF, Nicot F, Picard A, Boelle PY, Clément A, Vazquez MP. Facial side effects during noninvasive positive pressure ventilation in children. Intensive Care Med 2005;31(7):965969.

21. Chidini G, Calderini E, Cesana BM, Gandini C, Prandi E, Pelosi P. Noninvasive continuous positive airway pressure in acute respiratory failure: helmet versus facial mask. Pediatrics 2010;126(2):e330-e336.

22. Chidini G, Piastra M, Marchesi T, De Luca D, Napolitano L, Salvo I, et al. Continuous positive airway pressure with helmet versus mask in infants with bronchiolitis: an RCT. Pediatrics 2015;135(4):e868-e875.

23. Velasco Arnaiz E, Cambra Lasaosa FJ, Hernández Platero L, Millán García Del Real N, Pons Òdena M. Is nasopharyngeal tube effective as interface to provide bilevel non-invasive ventilation? Respir Care 2014;59(4):510-517.

24. Ramirez A, Delord V, Khirani S, Leroux K, Cassier S, Kadlub N, et al. Interfaces for long-term noninvasive positive pressure ventilation in children. Intensive Care Med 2012;38(4):655-662.

25. Antonaglia V, Ferluga M, Molino R, Lucangelo U, Peratoner A, Roman-Pognuz E, et al. Comparison of noninvasive ventilation by sequential use of mask and helmet versus mask in acute exacerbation of chronic obstructive pulmonary disease: a preliminary study. Respiration 2011;82(2):148-154
26. Mayordomo-Colunga J, Medina A, Rey C, Concha A, Los Arcos M, Menéndez S. Helmet-delivered continuous positive airway pressure with heliox in respiratory syncytial virus bronchiolitis. Acta Paediatr 2010;99(2):308-311.

27. Visscher MO, White C, Jones JM, Cahill, T, Jones DC, Pan BS. Face masks for noninvasive ventilation: fit, excess skin hydration, and pressure ulcers. Respir Care 2015:60(11):1536-1547.

28. Visscher MO. Imaging skin: past, present and future perspectives. G Ital Dermatol Venereol 2010;145(1):11-27.

29. Gerhardt LC, Strässle V, Lenz A, Spencer ND, Derler S. Influence of epidermal hydration on the friction of human skin against textiles. J R Soc Interface 2008;5(28):1317-1328.

30. Fraticelli AT, Lellouche F, L'her E, Taillé S, Mancebo J, Brochard L. Physiological effects of different interfaces during noninvasive ventilation for acute respiratory failure. Crit Care Med 2009;37(3): 939-945.

31. Girault C, Briel A, Benichou J, Hellot MF, Dachraoui F, Tamion F, Bonmarchand G. Interface strategy during noninvasive positive pressure ventilation for hypercapnic acute respiratory failure. Crit Care Med 2009;37(1):124-131.

32. Sferrazza Papa GF, Di Marco F, Akoumianaki E, Brochard L. Recent advances in interfaces for non-invasive ventilation: from bench studies to practical issues. Minerva Anestesiol 2012;78(10):11461153. 